\title{
Effects and impact of witchcraft on Sotho Reformed Churches and the Biblical view of witchcraft
}

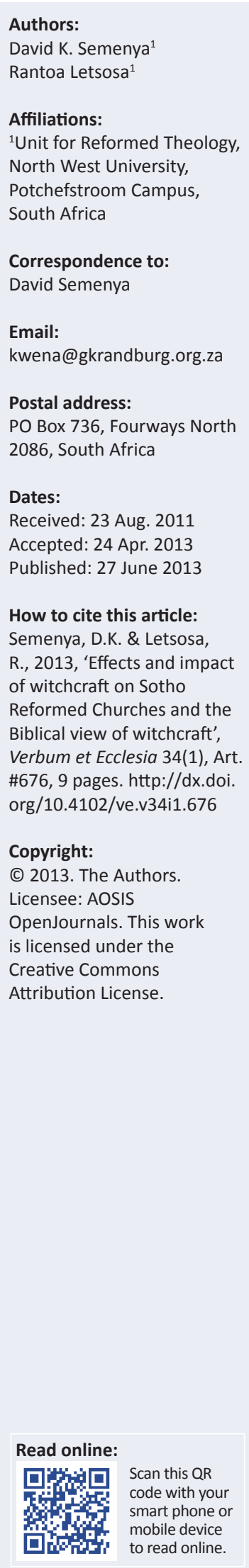

The aim of this article is to analyse the effects and impact of witchcraft on members of the Basotho Reformed Church who ascribe to witchcraft. From the literature, it is clear that some members of the Basotho Reformed Church practise various forms of witchcraft. Some Christians do not directly involve themselves with practices linked to witchcraft but do participate in healing practices. This article highlights a number of such instances and provides a number of guidelines to churchgoers who are adhering to practices of witchcraft. These guidelines should be relevant to them when they are reflecting on their relationship with the Lord with the aim to live in obedience to God's Word.

\section{Introduction}

During 1990 and 1991, 300 cases of witchcraft were reported, and 600 people, who were accused of witchcraft, lost their lives in Limpopo. It is by no mistake that the South African government passed legislation in 1957 prohibiting the practice of witchcraft. Recently, police in Mecklenburg, Limpopo, arrested a 55-year-old man for allegedly setting alight the house of a 70-year-old woman after suspecting her of killing his son through witchcraft (Matlala 2012). This shows how witchcraft has an impact on people.

It is a fact that some Basotho engage in witchcraft knowingly or unknowingly. Semenya (2007:66) showed that three out of the 60 respondents that he interviewed supported the view that Christians should become involved in the practice of witchcraft, and four of the interviewees considered witchcraft a gift from God, indicating that they do not see anything wrong with participating in the practice of witchcraft. In some instances, it also became clear that some of the respondents are afraid of witchcraft. However, more than $10 \%$ of the interviewees in principle have no problem with practices of witchcraft. It is clear that there are a number of factors that prompt people to engage in witchcraft, which are in many ways related to the issue of witchcraft itself. These aspects are limited cosmic good, fear, ancestral spirits and witchdoctors. These aspects will be discussed and evaluated from a Biblical perspective.

Harriet (1996:328) correctly states that most people believe in witchcraft, and for them, witchcraft does have a negative effect on society. He goes on to say that most people consider witchcraft to be the greatest cause of misfortune and that nothing harmful ever occurs by chance, which means that Africans can only be blessed with good things in their lives if witchcraft is addressed. This article attempts to conduct a brief study into a cultural analysis and the implications of witchcraft, within the context of the Basotho in the North-West region. It also attempts to provide a critical Scriptural evaluation.

\section{Witchcraft: An overview}

Witchcraft has a number of negative effects on people. A few aspects are analysed and critically evaluated in this article. These aspects are directly linked to witchcraft since the members of the Basotho Reformed Church feel that these are the factors that give rise to witchcraft and that consequently have an adverse impact on the people that are believed to be bewitched. However it is compelling for the authors to give first the definition of witchcraft so that the reader may know what the writer's intentions are regarding the topic. Thereafter some of the aspects that are linked to witchcraft are mentioned and analysed.

\section{Definition of witchcraft}

Africans view witchcraft as something evil and potentially harmful to people. It is, therefore, no surprise that anyone suspected of practising witchcraft within the community is immediately killed or harassed in different ways by members of the community. This is evident in many parts of the countries that make up the African continent, including South Africa. Khunou (2001) defines 
witchcraft as a satanic spiritual power practised by thousands of people, knowingly or otherwise, in order to advance the kingdom of Satan. It includes verbal abuse and magical spells of which the result is always the same: devastation, poverty, divorce, mental derangement and mental slavery. Witchcraft is the supposed power of a person to harm others by occult or supernatural means (Hayes 1995:339). Trapido (2010), however, reports that self-proclaimed witches have rejected the type of definitions pointed out by Khunou and Hayes on the grounds that these kinds of definitions stereotype witchcraft as harmful and portray witches as dangerous to the communities within which they live and work. Nevertheless, Basotho culture maintains that witchcraft is a detrimental practice that can bring evil, bad luck and poverty into their lives. This is why they respond with violence towards those suspected of practising witchcraft.

The abovementioned definitions of witchcraft conform to the definition that we find in the Bible. In the Old Testament, the Hebrew word for witch is מכשפה. This word is usually associated with sorcery, secret communication with another world and divination - although divination can be studied as a separate subject field (cf. Ex 22:18; Dt 18:10; 2 Ki 9:22; 2 Chr 33:6; Mi 5:12; Nah 3:4).

Directly related to the abovementioned definition is the way in which the Septuagint and the New Testament define

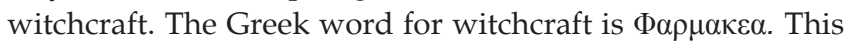
term implies the taking of drugs, probably to produce clouds of vapour, as part of the process. In Revelation 9:21; 21:8;

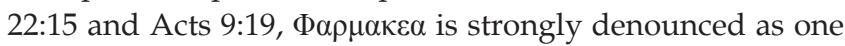
of the sinful works of the flesh.

\section{Different types of witches}

In view of the abovementioned definition of witchcraft, it is obvious why witchcraft is not favoured amongst the Basotho nation. Kgatla (1995:21-22) includes, from the modern Basotho context, two types of witches to show how witchcraft can be detrimental to people: night witches and day witches. He also describes a number of the techniques which they use to harm or kill others.

\section{Night witches}

Kgatla (1995:21-22) explains that witches are born with an inherent quality for evil as the snake is born with its venom. They have a compulsion to do evil, which needs to be activated by jealousy or hatred as in the case of day witches. This is their nature that compels them to harm others purely for the sake of the pleasure they derive from it. They mainly work during the night, but they may also work by day should they see an opportunity to bewitch others.

Kgatla (1995:21-22) goes on to offer the valuable fact that these night witches are able to directly and without the aid of any substance effect their evil purpose. They are believed to walk around naked at night, even on the coldest of winter nights. They smear their bodies with ash to disguise the fact that they are witches and are able to run faster than under normal circumstances. People fear them. It is believed that they are at their strongest around $02 \mathrm{~h} 00$ and that, by this time, they have held their regular meetings and are then executing their plans.

\section{Day witches}

These are ordinary individuals who, by means of medicine obtained from various experts, attempt to kill their enemies or even innocent people. Their notoriety lies in the fact that they are so dangerous. They attack their target in broad daylight and never miss an opportunity to bewitch their victims.

The night witches make use of ordinary animals like hyenas, big dogs, mongooses, owls, snakes or lightning birds. They have the skill to tame these animals and hide them at the back of their huts.

The day witches are especially active at festivals where liquor and food are served. Their practices include sending snakes to bite their victims or lightning to strike them down. They may also collect the victim's hair, nail clippings or any article of clothing worn by the victim to cast a spell on it that will harm or kill their victims (Nyirongo 1997:185).

\section{Witchcraft amongst Basotho Christians}

\section{Limited cosmic good}

The issue of limited cosmic good has been a familiar concept to the Basotho for a very long time. This may have developed from the way in which Black people have been treated in the past. Due to the 1913 Land Act, the Basotho people were restricted to the extent that they had no way of accumulating any degree of economic prosperity as was possible for their White counterparts (cf. Robertson 1991:47).

Yet Van Rooy (1978:7-8) notes that the background to black cosmology denotes, to a large extent, the notion of limited cosmic good as is the case in many other traditional cultures. This idea is typical in subsistence societies where there are seemingly limited natural resources. However, in expanding societies, such as modern industrial societies, the assertions by the two scholars above could easily be refuted.

Limited cosmic good can best be understood in the context of jealousy. It holds that nothing good should happen to my fellow man if I do not also benefit from it in some way. If it were to happen that someone prospers without my partaking in it, the presence of witchcraft would be suspected. It is believed that the degree of good possessed or controlled by a particular person can only be increased at the expense of someone or something else. Should prosperity seem to be declining, the logical conclusion would be that it is being drawn away from somewhere else (Muthwadini 1990:3). 


\section{The fear of being bewitched}

Many of the Basotho live with the fear of being bewitched and, therefore, visit dingaka tsa setso [traditional doctors] to obtain traditional herbs to shield them or their property (family, house, car or animals) against witchcraft. The fear arises from suspicion in most instances, and this suspicion then leads to hatred. Hatred in turn leads to anger, which then leads to witchcraft. This is a vicious circle that goes from fearing witchcraft to turning oneself into a witch or fellow witch because the Basotho would normally visit traditional doctors for their protection against witchcraft. The moment one consults with traditional doctors, it implies that other people are witches and you thus want to strengthen yourself against them. This involves you indirectly in the vicious circle.

It is a fact that the Basotho fear witchcraft and that they see witchcraft practices as something that God will punish in the end. A number of the members of the Basotho Reformed Church interviewed by Semenya (2007:65) indicated that God would punish those engaging themselves in witchcraft practices. This shows how those practising witchcraft are viewed as evil and deserving punishment.

From an interview conducted by Deborah Patta, the presenter at e.TV's Third Degree (Patta 2006), it was evident that people abhor witchcraft and regard it as the main enemy of the community. This is also the reason why many people suspected of witchcraft have been killed. The most unfortunate part of all this is that some of them died innocently, with being suspected of being witches as their only crime. Hence, it has become a crime to accuse someone of witchcraft in South Africa without any real proof. This law was instituted to prevent people from raising suspicions in order to camouflage their dealings with their enemies. Witchcraft is thus practised by many people for various reasons, and they are not easily identified because moloi ga a na mmala [a witch does not have colour].

\section{Life-force or vital force}

The idea of life-force goes hand in hand with that of limited cosmic good. For example, when people are not prosperous or when their goods are limited, they will argue that someone has taken their life-force.

Life and death are not absolute concepts to Africans as they are to Europeans. They are rather relative concepts with no clear dividing line between the two. Life to Africans is a dynamic process of a constant increase or decrease in vital force. An African would say 'he has killed me' when forced to pay an excessive price or receiving an excessive punishment or receiving inadequate payment for strenuous labour. All these mean that the vital force of the speaker is being diminished. Against this background, it is clear why Africans seek means to increase their life-force when sensing the approach of witchcraft (Van Rooy 1978:8).

Witches also increase their life-force to gain strength. The most frightening thing is that they increase their life-force by feeding on human flesh. In addition thereto, Van Rooy (1978:7-8) says that witches especially kill the young, whose life-force is still strong, in order to increase their life-force and because older people's flesh is tough and not as good since their life-force is too weak being so close to death. When they kill older persons, it is not to consume their flesh but out of vindictiveness (Musopule 1993).

\section{Traditional ways of increasing life-force}

The Basotho believed that one's life force could only be increased by way of obtaining traditional medicines from the witchdoctors and also by wearing some amulets (Semenya 2007:54). It seems that this idea of an increasing life force is an idea that many of the African people hold. For them, it is not a problem to consult with a traditional doctor for the increment of their life force. It is believed that some part of the body will be cut with a razor blade, and a mixture of traditional medicine or a fatty black substance will be smeared into these cuttings. The cuts are especially made on the top of the head, the forehead, the back and the various joints of the body. This is done at least once a year. The increase of life-force is done to counteract the power of witchcraft. Most Africans, therefore, do not blink an eye when hearing people say that they want to go to a witchdoctor for a recharge. This shows how witchcraft has an impact on the life of African people (Semenya 2007:54).

\section{Witchdoctors}

Witchdoctors are practicing witches, meaning that they may well have certain affinities to witches (Parrinder 1963:182-183). Witchdoctors do not hide themselves. People go to witchdoctors for consultation and to protect themselves against witchcraft. The main aim of the witchdoctor is more to protect than to attack. However, in order to protect, they at times also have to attack and thereby have something of the same spirit. They have to be like witches so that they may overcome their powerful spirit, and so witchdoctors have a power similar to that of witches. This power enables them to recognise those who are using witchcraft and heal those who are bewitched, but the power is very delicate and is fraught with danger to the possessor.

It is evident that, if witchdoctors are not strong enough to defeat the power of a witch, their attempt to heal or to ward off the witches may backfire, and they themselves may be put in danger. In defining witches, the writers argue that, whilst witches are not necessarily visible and cannot easily be identified, witchdoctors are more like pastoral workers in their community - there to give advice and to ward off evil. Whilst the sole aim of witches is to cast spells and bewitch, witchdoctors try to fight it. Setiloane (1976:46-47) mentions four types of witchdoctors (ngaka), and he describes them as follows.

\section{Selaodi [the diviner]}

The diviners use a set of stones, shells and engraved stones which they carry in a small skin bag. These they throw on 
the ground, and the pattern in which they fall reveals the answer of their ancestors to their client's enquiries. Enquiries may relate to the nature and causes of sickness, the reason for a death, the whereabouts of missing stock or any baffling situation or a desire to know something about the future.

\section{Senoge [one who smells out or one who divines without a set of stones]}

A senoge touches the enquirer or, in the latter's absence, a piece of his or her clothing, and the ancestors with whom the enquirer is in close and constant contact then communicates the required information. People consult a senoge on more serious matters that encompass a wider social circle than just the family or single individuals. The acquisition of this skill does not require apprenticeship and is a direct gift from badimo or the spirits of the ancestors, frequently recognised in early childhood. Through illness, the badimo bloom in the person they call, and after recognition by other dinoge, the skill is endorsed, enlarged and liberated through pha badimo [thanksgiving to the ancestors].

\section{Lethugela [one who divines through spirit possesions]}

This type of a witchdoctor is mainly of Nguni origin and is often a woman. They specialise in the treatment of possession by spirits of which the most common symptom is violent headaches. They work in teams, beating drums and dancing. They claim inspiration and support from supernatural forces but rely less on the badimo than does the selaodi or senoge.

\section{Dingaka tse dinaka [horned doctors]}

They are called horn doctors because they keep their medicine or ditlhare in hollow horns. Their medicines are mixed together with animal fat or Vaseline in a horn and supplied for the protection of a homestead against unseen evil influences. Their added function is to ward off sorcery. This type of witchdoctor may simultaneously practice as a selaodi or senoge and indeed almost invariably use ditaola [sets of stones] in their practice. Their services are more generally sought in the performance of rites addressed to the badimo. It is, therefore, clear that all these types of witchdoctors are directly connected to the badimo.

\section{Methods of witch cleansing in a traditional African perspective}

Four decades ago, Douglas (1970:129) stated that, in most African societies, witchcraft is regarded as a cause of what is seen by the sufferer as unmerited misfortune. Usually magical means are available to individuals who feel threatened by witchcraft so that they can defend themselves. Such prophylactics are dispensed to their clients by local specialists: the witchdoctors of traditional Africa.

There are medicines that witchdoctors use to ward off disease and not only disease but also robbery, witchcraft lightning and all sorts of misfortunes and disasters. These prophylactics fall into two classes, namely the preventive medicine and the medicine used to bewitch others (cf. Munday 1951:17-18; Parrinder 1963:187-189).
Regarding the method for cure, Setiloane (1976:54) argues that witchcraft cleansing also falls in two categories: prevention and the healing of those who have been bewitched. Prevention involves the application of the lenaka [horn] to strategic points such as the doorposts of the house, the corners of the lapa, the fields and the cattle kraal. The head of the household preserves the lenaka [the horn with its contents], and it is refilled annually for use in the rite of go theya motse [to make a house strong against witches]. The witchdoctor may or may not take part in this.

Another sethare or leswalo [curative medicine], is a fatty substance rubbed on the face and body to make a person likeable. One may not be physically ill when this is done for the first time. Another function of leswalo is to make witches blind to the prosperity of the person receiving the treatment and, therefore, forgetful of their jealousy and destructive impulses. Another method is to cut parts of the body, usually the top of the head, the forehead, the back and the joints on the hands and legs (Kgatla 1995:23).

The other two methods of healing or cleansing are mokhubetso and moupelo. Mokhubetso [incense] is burned, preferably on red-hot cow dung. Its smell drives away witches and it also cleanses the atmosphere of difatlhi [those who make people not recognise their blessings] and promotes the uninterrupted growth of infants. Moupelo [traditional medicine made of birds' nests, birds, locusts and feathers from any kind of birds, turned to ashes and spread all over the farm], which is often part of the ingredients of lenaka, prevents the birds from eating the millet and reduces the multiplication and destructiveness of the maize stalk borer in the fields. It is invariably included in the medicine used in the ritual of seed cleansing (Kgatla 1995:23).

Semenya (2007:49) mentions the following methods of healing and/or witch cleansing that are also used:

- Seipone [mirror]: A cup full of a mixture of traditional medicine is given to the person. After a few minutes, the person is led to a dark room where he or she will start seeing those who are bewitching him or her. This kind of therapy helps the individuals to be careful about whom they see in the seipone.

- Ditlhare [curative medicine] may be given orally, by external application or by incision.

- Sejeso [poison eaten by the victim] may be treated with pitsa [boiled medicine], an emetic or a laxative and is the most common method.

The evil witchcraft paradigm cannot be separated in practice from the African paradigm for the good focus on ancestral spirits as the guardians and protectors of life, health, peace, harmony and order in society. Indeed failure to respect the ancestral spirits and to observe the social code of behaviour which they endorse results not only in losing their protection, but it also renders believers highly vulnerable to witchcraft attack. If ancestors are not respected, it may lead directly to disease or the withholding of their protection and allowing other ills to arise. Just as illness, misfortune, disorder and 
death are directly associated with witchcraft, so health, good fortune, order and life are perceived as inseparable from good relations with the world of ancestral spirits (Dillon-Malone 1987:36; Welbourn 1972:233). Hence, many people turn to their ancestors for protection against witchcraft. Setiloane (1976:64) calls ancestral spirits the living dead and adds that, upon death, all initiated Basotho-Batswana become badimo or ancestral spirits. Babies are gifts from the badimo, and they grow up to be initiated as adults. At death, they again change their state to serve as the immediate agents of God. They are viewed as closer to God than others and live in a realm of spiritual realities. People have an ambivalent attitude towards ancestors, loving and fearing them depending on the circumstances. They are generally expected to be protective and beneficent, even if they were not like that in their earthly lives (Thorpe 1991:113).

The function of the ancestors is to ensure the good order of social relationships amongst the biological living as well as the fertility and well-being of men, their crops and stock. In return, they expect tirelo [service]. This tirelo is also called mpho ya badimo [a gift to the ancestors] and in the African context usually take the form of slaughtering for the departed. They offer sacrifices to appease the departed and thereby hope to gain their favour (Letšosa 2005:231).

\section{Biblical evaluation of the aspects and methods of cure linked to witchcraft}

One of the aspects linked to witchcraft is limited cosmic good. On the issue of limited cosmic good Semenya (2007:66) reasons that some of the members of the Basotho Reformed Church believe that limited cosmic good can be taken away. However, in reality, cosmic good comes from God and cannot be obtained by taking it from someone else.

In the light of Ecclesiastes 3:13, Zuck (1991) argues that God is the source of all good and that people have a responsibility to work so that they may enjoy life. Many people find no end to the toil of life, sometimes because they are driven by the envy of what other people possess. Though work may be seen as bringing disparity unto the life of people, it can be enjoyed when seen as a gift from God. Furthermore, Wiersbe (1996) states that viewing work as a gift from God is an encouragement that man should enjoy, no matter how difficult the kind of work may be. This means that cosmic good is not limited because God is not limited. God is the source of unlimited wealth and life and power. His resources are inexhaustible; they can never be depleted. There is always more than enough for everyone. However, these resources need responsibility amongst people to enjoy God's calling towards work.

When dealing with 1 Thessalonians 4:11-12, Wanamaker (1990) argues that it is improbable for Christians to remain idle and not to work with their own hands because that would make them depending on others economically. Hence God has given each and every one the ability to work. Should this very text be interpreted within the context of limited cosmic good, which gives rise to witchcraft, one could argue that Paul is saying: Do not envy other people's things with evil in your heart because you will end up bewitching them to get what does not belong to you. Instead work hard so that people may see your blessings and become encouraged to also work hard. African people cannot call upon the concept of Ubuntu in this context since Ubuntu in no way encourages laziness. Ubuntu rather calls on the cooperation of the community to work together, help one another and support one another to survive. No-one should depend upon the other and do nothing.

There is no doubt that fear is one of the aspects linked to witchcraft. The word for fear in Hebrew is yara'. In the Old Testament, the word fear has a three-fold meaning, namely dread or terror in Deuteronomy 1:29 and John 1:10, to stand in awe (with reference to a king) in 1 Kings 3:28 and to revere or to respect (with regards to parents) in Leviticus 19:3. This means that the proper kind of fear is that which causes one to stand in awe, to revere, to respect.

Christians should fear God and not man (Mt 10:28). This kind of fear has been expressed by the early church that walked in the fear of the Lord (Acts 9:31). The fear of the Lord should be expressed in reverential submission to his will. Whoever fears the Lord finds it easy to hate evil $(\operatorname{Pr} 8: 13)$ and thus have a prolonged life (Pr 10:27) and, most importantly, turn from evil (Pr 16:6; cf. Reyburn \& Fry 2000; Neptune, Bros \& Elwell 1995).

However, without the fear of the Lord, one is deprived of the treasures of God's wisdom and knowledge. One then becomes susceptible to evil and to being corrupted by it since true wisdom is only to be found in the fear of the Lord and true understanding in the knowledge of holy things. This is how the fear of the Lord differs from the fear of man because the fear of man sets a trap ( $\operatorname{Pr} 29: 25)$. When people live in fear of other people, they will constantly be preoccupied with the evil things others may do to them. That is different from the fear of the Lord (cf. Biblical Studies Press 2006; Newheiser 2008).

God is always at work (cf. Jn 5:17) and in control (Borchert 2001; Nolland 2005) despite the apparent arbitrariness of many events in the world. This fact calls on man not to fear anything because, without God's consent, not even the sparrows can die or one hair can fall off man's head. God is the Creator and the Sustainer of his creation, and the Lord has not left the human race to hopelessness (Pfeiffer 1962). The Lord's reign gives a clear indication that all his provision do not come from ancestral spirits. They come from the Lord - the blessings, the light and also the darkness (cf. Is 45:7).

The power to love (cf. Cor 13) is able to counter-attack the power of evil for it strikes at the root of evil (Lagerwerf 1985:18). The most essential point is to develop a living faith in God the Father. He who cares for the birds, will he not care even more for people? 
When a Mosotho is less fortunate he or she would always suspect that he or she is bewitched, therefore make ways to increase his or her life force. Things like amulets, badges and traditional medicines are therefore used either to enlarge one's life force or to ward off witches (Henry 1996; Lagerwerf 1985:29). The questions that remain to be answered are whether these amulets, badges and traditional medicines really increase or even enlarge life force. Besides amulets, badges and traditional medicines (Semenya 2007:54-55) mentions some of the things that are mostly used to ward off the witches and to increase their life force:

- Sewasho: a mixture of medicine and ashes, applied to the face to gain favour with witches. It may also be poured into a person's bathwater, to ward off witches or have the strength to resist them.

- Meetse a thapelo: This is normally water from the ocean. Before it is given to the person, someone or a priest who is a prophet blesses the water by means of a prayer, and it is then given to the person in need. The water may be drunk or poured into a person's bathwater before washing. Some carry little glass bottles containing this kind of water wherever they go so that they may look like a real person. The unemployed often go to these prophets for these little glass bottles in order to obtain employment.

- Letsoai [coarse salt]: It is blessed with prayer by a priest before it can be distributed. It is thrown around the house or inside the yard with the purpose to strengthen the house against witchcraft.

- Most ZCC members use tea (especially Joko tea, Trekker tea, Five Roses tea and cacao coffee) mixed with milk. The mixture depends on the illness of the person, that is, if the person is seriously ill strong tea is given and if the person is less ill a mild tea is dispensed. The ill person may drink the tea or may use a syringe bulb to remove any sejeso [poison] (Semenya 2007:55).

- $k a p a$ is another way of healing whereby lukewarm watersometimes mixed with medicine or coarse salt or vinegar - is given to the ill person. O kapâ is the drinking of a large amount of water and then sticking a finger down the throat to induce vomiting. This vomiting rids the person all the poison or evil.

- Sefotho is a mixture of medicine poured in a big dish with boiling water, over which the person leans covered by a blanket to sweat excessively, like a modern sauna.

Furthermore, The Christian separatist sects use cleansing medicines, just like the herbal remedies of the witchdoctors, to counteract witchcraft or to heal themselves. In most cases, they distribute it in modern glass bottles. If the sect should oppose the use of all medicine - be it European or African - and rely on 'faith healing', recourse may be taken by anointing with oil, sprinkling with holy water, rubbing with ashes or censing with incense (Parrinder 1963:189-190).

The Christians in separatist sects treat many kinds of illness, like for instance hypertension. This is treated by pinning the nose and foot of the person with the belief that, when the pent-up blood from the nose and the foot is released, the hypertension will abate. In that way, people also find additional means of protection within the church. In the Roman Catholic Church, there are devotional objects like holy water, the rosary, medals and prayer books. The cross, holy candles, church bells and consecrated herbs are used as means to ward off witches. Having rejected these devotional objects from the very beginning of their existence in Africa, Protestant churches lost many members to the African Initiated Churches. Others stayed in their church but live a double life (cf. Lagerwerf 1985:29; Sebald 1978:217). To add to that, Mapumulo (2012) recently reported that Reverend Mautji Pataki of the South African Council of Churches asserted that the reason why mainline churches, including Reformed churches, in South Africa experience a sharp decrease in membership is that people nowadays believe in what they can see and touch. Unfortunately mainline churches have rejected any devotional objects in their churches.

One cannot, however, refute the reason why the Reformers, Luther and Calvin, shifted their theological guidance from the ecclesiastical tradition to a greater reliance on Scripture and faith. Ecclesiastical practices as well as old folk magic used to ward off the devil and his witches - were condemned as superstition, even blasphemy, and to a large extent became alien to the Protestant faith in God, regarded as the infallible shield against Satan and his witches (Sebald 1978:216-217). These Protestants were ignorant of the African worldview and simply wrote off every practice as barbaric or heathen, failing to teach people in a pastoral manner how to deal with their fears. Africans resorted to living double lives and practising syncretism. On Sundays, they are Christians, and on weekdays, traditional African people hold on to their beliefs. Now Protestant churches are faced with this dilemma and with the question whether they should reject it summarily. Witchcraft is a reality for African people. Ministers are faced with members who are fighting the issues of witchcraft and bad luck on a daily basis.

In view of John 17:3, Lloyd-Jones (1963) argued that the evangelist defines 'eternal life' for the readers as not just unending life in the sense of a prolonged duration. Rather it is a quality of life with its qualitativeness derived from a relationship with God through his Son Jesus Christ (cf. 1 Jn 5:11-12). Eims (2002) underscores this by saying that the real life can only be received through Christ. Moreover, Gangel (2000) points out that Christ's definition of eternal life is important, because it differs from the current concept of endless existence. The word 'know' in verse 3 is $\gamma \mathbf{v} \omega \sigma \kappa \omega$ emphasising an experiential relationship rather than just having the necessary information. The verb also appears here in the present tense, suggesting a continuing personal experience and contact with both the Father and the Son. 
Just as the Father is self-sufficient, having within himself eternal life (cf. Jn 5:26), so also the Son has this life (inherent) in himself, and this explains the fact that he is able to grant everlasting life to his elect (Hendriksen \& Kistemaker 2001). From the Biblical point of view, one may conclude that amulets and badges cannot give a person life or increase ones life-force; their power is imaginary. The only real life is in Jesus Christ who is the source of life. This means that whoever has Jesus Christ possesses eternal life. Therefore there is no need for one to try to increase one's life force.

God asserted his authority in Exodus 20:3 when he said: 'I am the Lord thy God', meaning that he is the sole object of religious worship as required by the first four commandments. The Israelites are here bound to obedience by a threefold cord, which - one would think - could not easily be broken. Firstly, because God is the Lord - Yahweh, self-existent, independent, eternal and the fountain of all life and power - he had the incontestable right to command them. Since he gives life, he may also institute law, and therefore, he was able to bear them out in obedience, to reward obedience and to punish disobedience. Secondly, he was their God, a God in covenant with them and their God by their own consent. Therefore, they were to keep the commandments. Refusal to do so, would amount to unfaithfulness, injustice and ingratitude in the eyes of the Lord (Henry 1996). This argument clearly shows that ancestors have no place in anyone's life since there is only one God (cf. Is 44:6).

The other aspect that is linked to witchcraft is witchdoctors. The one thing that one cannot ignore is the fact that those who consult with the witchdoctors often make claims that they are healed. The question is how one would then give advice to such people from a Biblical point of view? It is well known that the spirit has a strong power over the body. If the spirit tells the body that the person is healed, the body will often believe it and react accordingly. This is often referred to as psychological cure, which means that it is not necessarily the witchdoctor who has healed a person. However, one should be more careful because Satan can use people to pursue his own evil purposes. He is an imitator and is able to deceive many. Christians should not be led astray by their heart's desires and should rely on the Word and the faithfulness of the Lord (cf. Pr 17:22; 14:30). God makes use of the living to communicate with the living (cf. Bae \& Van der Merwe 2008:1302; Muthwadini 1990:22-23; Walvoord \& Zuck 1983).

Taking into consideration the arguments above, one could observe that a human being is weak and mortal in contrast to God who is spirit, powerful and immortal. Because of this inherent difference between man and God, there is no justification for man to have confidence in muti something provided by witchdoctors - rather than trusting in God. Looking at Jeremiah 17:7, Richards (1991) carries the argument to the extreme by trying to show how man should trust in God rather than in anything else. His conclusion thus highlights the fact that God blesses those who trust in him, rather than in other things.

On the same note, Clendenen (2007) elaborates that people should place their trust in the Lord and in the Lord only. This faithful trust in God should not be doubtful or hesitant but should be a bold attachment to a strong resource that is unfailing. Such trust will quickly lead to joyous singing. He further argues that the trust in the Lord should reflect a picture of confidence, joy in commitment and total dependence on God (cf. Is 12:2). As God was the salvation of the Israelites during the exodus (cf. Ex 14:13-14; 15:1-18), so God will become the salvation of future generations.

God deserves man's trust because he provides for the necessary protection against witchcraft. It can therefore be argued that a belief in Christ should be a central focal point since it gives assurance of the Holy Spirit who protects his people against any form of witchcraft. Trust should not be placed in inanimate objects or water that has been prayed or oil used to anoint but rather in Jesus Christ who heals and protects since there is a danger that these other things divert focus away from the real Saviour, Jesus Christ. Only God Almighty can drive away witches through his power and his mercy. He gave his only begotten Son to come and cleanse us from evil. Through the blood of his Son, our Lord Jesus Christ, those who believe in him are cleansed. There is no need for people to seek any other cleansing than the cleansing from God (cf. 1 Jn 1:7, 9). Whenever God is present, the evil spirit departs (1 Sm 16:23).

\section{Practical guidelines}

Basotho say moloi ha a na mmala which means that a witch does not have colour, as has been mentioned. This means that no person can say whether someone is a witch merely by looking at the person.

Important to note is that believers, like all other people, are still persecuted by the devil. For this reason, they also easily run for help just like the non-believers. The following guidelines are thus given to them as well as to those counselling them.

Members must be taught through sermons about matters relating to the sin of witchcraft. It also remains the responsibility of the members to study the Word of God on their own and to become part of Bible study groups or cell groups so that they may get to understand the Bible well.

In addition to this, church activities such as conferences and seminars must be used as opportunities to teach members concerning the sin of witchcraft. Should there be members who feel threatened by the powers of witchcraft and who are affected in one way or another, counselling by means of the Word of God should be conducted, and moreover members should be encouraged to consult their ministers. 
It is equally important that love towards man and God should also be clarified to those struggling with fear. When dealing with the relationship between the counsellor and the counselee, Adams (1973:416) argues that the fear seems to stem from the fear of what either God or other humans may do to them. He mentions that the summary of the Law should be of great interest since it consists of a message of love towards God and humans. Love towards God means focusing upon how one may trust, worship and serve him. Love towards one's neighbour likewise focuses upon being in a relationship with the neighbour. Christian counsellors must determine the source of fear and meet it by the proper call to repentance and love. If counselees fear God, their relationship with God must be explored. If counselees' fear is fundamentally a fear of man, the answer lies in encouraging them to engage in loving ministry wherein they may give of themselves to others. The fear of God is the one that removes all other fears. The opponent of fear is love: The way to put off fear is to put on love. Love moves towards others, fear shrinks away from them.

Moreover, believers should remember that witchcraft is sin and is punishable by God. Therefore, believers should avoid consulting with witchdoctors for protection. One should note that some of the witchdoctors use magical potions just as they are used by witches. Therefore believers should rather ask God for protection.

Despite the fact that believers are persecuted by the devil, they are assured of the protection of the Holy Spirit who is always with them. Where the Spirit is present, there is no fear because believers have received the Spirit of power and boldness and not of fear. Therefore there is no need for members to put on or carry amulets and traditional and prophetic medicines since these cannot protect them. Neither can these add life-force: Members must be assured and comforted by the message that by believing in Jesus Christ they inherit eternal life (Jn 1:25-26).

\section{Conclusion}

It is a fact that witchcraft is viewed as a threat to the community, and witches are regarded as a great evil and the most hated and feared creatures on earth. At the same time, people seek different means to protect themselves, and in this way, witchcraft has an impact on people. In empirical research done by the authors, members of the Basotho Reformed Church indicated that they would not shy away from informing their church about their worshipping of ancestors or even of their consultation of witchdoctors despite the fact that the person knows that the word of God condemns such practices. This points to open syncretism in the Basotho Reformed churches that needs to be addressed.

This article outlined and discussed very specific aspects concerning witchcraft that, if ignored, would escalate and have a negative effect and impact on the members of the church, in this case the Basotho members of Reformed churches. Therefore it is the responsibility of the churches concerned to engage openly and freely with their members with regard to the discussed aspects, taking into consideration what God says about the aspects that were discussed. This would lessen the existing effects and impact that members are currently experiencing.

\section{Acknowledgements Competing interests}

The authors declare that they have no financial or personal relationship(s) that may have inappropriately influenced them in writing this article.

\section{Authors' contributions}

D.K.S. (North West University) compiled the manuscript and R.L. (North West University) performed most of the editing.

\section{References}

Adams, J.E., 1973, The Christian counsellor's manual, Presbyterian and Reformed, Westminster.

Bae, C.S. \& Van der Merwe, P.J., 2008, 'Ancestor worship: Is it Biblical?', HTS Teologiese Studies/Theological Studies 64(3), 1299-1325.

Biblical studies press, 2006, The NET Bible first edition notes., Biblical Studies Press, USA.

Borchert, G.L., 2001, The new American commentary: John 1-11, vol. 25B, CD-ROM, Logos Research Systems,Inc., Broadman \& Holman Publishers, Nashville.

Clendenen, E.R., 2007, Isaiah 1-39, New American commentary, B \& H Publishing Group, Nashville.

Dillon-Malone, C., 1987, 'Witchcraft as a pastoral problem', Afer 29(f), 36-45.

Douglas, M., 1970, Witchcraft confession and accusation, Tavistock Publications, London.

Eims, L., 2002, Beginning with Christ, viewed 04 March 2012, from www. discipleshiplibrary.com

Gangel, K.O., 2000, 'Holman New Testament commentary', John Holman reference 4(313), Broadman \& Holman Publishers, Nashville, TN. PMid:10810476

Harriet, H., 1996, 'Witchcraft and the gospel: Insights from Africa', Missiology 4, 323-344.

Hayes, S., 1995, 'Christian response to witchcraft and sorcery', Missionalia 3, 339-354.

Hendriksen, W. \& Kistemaker, S.J., 2001, Exposition of the Gospel according to John, vol. 1 \& 2, New Testament commentary, Baker Book House, Grand Rapids.

Henry, M., 1996, Matthew Henry's commentary on the whole Bible: Complete and unabridged in one volume, Hendrickson, Peabody.

Kgatla, S.T., 1995, 'Remaining prophetic in a time of reconstruction and development', report delivered during the annual General Meeting of the Institute for Contextual Theology held in Braamfontein, Johannesburg from 01 to 03 August, Braamfontein, Johannesburg.

Khunou, M., 2001, 'Break the demonic chain through Jesus', Sowetan, 25 August, viewed 04 February 2012, from http://www.citypress.co.za

Lagerwerf, L., 1985, 'Witchcraft, sorcery and spirit possession: Pastoral response in Africa', Journal of the Southern African Missiological Society 17(J-L), 1-62.

Letšosa, R.S., 2005, 'A relevant liturgy for the reformed churches in synod Midlands', PhD Thesis, Potchefstroom Universiteit vir Christilike Hoër Universiteit, Potchefstroom.

Lloyd-Jones, D.M., 1963, The basis of Christian unity: An exposition of John 17 and Ephesians 4, Eerdmans, Grand Rapids.

Mapumulo, Z., 2012, 'Formal churches lose their flocks', City Press, 08 April, p. 6.

Matlala, A., 2012, 'Household torched after witchcraft allegations', Sowetan, 07 February 2012, from http://www.sowetanlive.co.za

Munday, J.T., 1951, Witchcraft in central Africa, Central Africa Press, London.

Musopule, A.C., 1993, 'Witchcraft terminology: The Bible and African Christian theology: An exercise in hermeneutics', Journal of Religion in Africa 23(N), 347354.

Muthwadini, J.A., 1990, The word of God for Africa, IRS Potchefstroom Universiteit vir Christilike Hoer Universiteit, Potchefstroom. 
Neptune, N.J., Bros, L. \& Elwell, W.A., 1995, Evangelical commentary on the Bible, vol. 3, Baker Book House, Grand Rapids.

Newheiser, J., 2008, Opening up Proverbs, Day One Publications, Leominster.

Nolland, J., 2005, The gospel of Mathew: A commentary on the Greek text, W.B. Eerdmans, Grand Rapids.

Nyirongo, L., 1997, The gods of Africa or the God of the Bible?: The snares of African traditional religion in Biblical perspective, IRS Potchefstroom Universiteit vir Christilike Hoër Universiteit, Potchefstroom.

Parrinder, E.G., 1963, African traditional religion, Hutchinson, London.

Patta, D., 2006, 'Cry witch', interview conducted on Third Degree on e-TV, 28 March 2006 at $8 \mathrm{pm}$.

Pfeiffer, C.F., 1962, The Wycliffe Bible commentary: Old Testament (Is 45:7-14), Moody Press, Chicago.

Reyburn, W.D. \& Fry, E.M., 2000, A handbook on Proverbs. UBS handbook series: Help for translators, United Bible Societies, New York.

Richards, L.O., 1991, The Bible reader's companion, CD-ROM, Victor Books, Wheaton. Robertson, A.F., 1991, Beyond family: The social organisation of human reproduction, University of California Press, Santa Barbara.

Sebald, H., 1978, Witchcraft the heritage of heresy, Elsevier, New York.
Semenya, D.K., 2007, 'Biblical counselling of Sotho Christians in synod Midlands believing in witchcraft', MA dissertation, North-West University, Potchefstroom Campus, Potchefstroom.

Setiloane, G.M., 1976, The image of God among the Sotho-Tswana, A.A. Balkema, Rotterdam.

Thorpe, S.A., 1991, African traditional religion: An introduction, Unisa, Pretoria.

Trapido, M., 2010, 'Make witchcraft a criminal offence', Mail and Guardian, 13 January, viewed 04 February 2012, from http://wwwmailandguardian.co.za

Van Rooy, J.A., 1978, The traditional worldview of black people in Southern Africa, IRS Potchefstroom Universiteit vir Christilike Hoër Universiteit, Potchefstroom. PMid:23390

Walvoord, J.F. \& Zuck, R.B., 1983, The Bible knowledge commentary: An exposition of the Scriptures (Is. 44:9), Victor Books, Wheaton.

Wanamaker, C.A., 1990, The epistles to the Thessalonians: A commentary on the Greek text, W.B. Eerdmans, Grand Rapids.

Welbourn, F.B., 1972, 'Bantu witchcraft and Christian morality: The encounter of Bantu Uchawi with Christian morality: An anthropological and theological study', Journal of Teligion in Africa 4(J-L), 233-234.

Wiersbe, W.W., 1996, Be satisfied, Eccl 3:9, CD-ROM, Victor Books, Wheaton.

Zuck, B.R., 1991, 'God and man in Ecclesiastes', Bibliotheca Sacra 148, 46-56. 